Gut, 1986, 27, 66-72

\title{
Ileal resection: effect of cimetidine and taurine on intrajejunal bile acid precipitation and lipid solubilisation
}

\author{
W J F FITZPATRICK, P L ZENTLER-MUNRO, AND T C NORTHFIELD \\ From the Norman Tanner Gastroenterology Unit, St James' Hospital and the Department of Medicine, St \\ George's Hospital Medical School, London
}

SUMMARY We have investigated whether pH-dependent bile acid precipitation limits lipid solubilisation after ileal resection, and whether treatment with cimetidine, or taurine improves solubilisation. Nine ileal resection patients were treated with placebo, cimetidine and taurine in random order for two weeks each. Upper jejunal content was aspirated and pooled according to $\mathrm{pH}$ for three hours after a standard Lundh test meal. On placebo, 50\% of the bile acids were precipitated at $\mathrm{pH}<5$, compared with only $26 \%$ at $\mathrm{pH}>6$, whilst aqueous-phase lipid concentration tended to be lower at $\mathrm{pH}<5$ than at $\mathrm{pH}>6(5.1 \mathrm{vs} 8.2 \mathrm{mmol} / \mathrm{l})$. On cimetidine mean $\mathrm{pH}$ rose, particularly during the third hour $(6.6$ vs $5.8, \mathrm{p}<0.05)$, associated with a reduction in bile acid precipitation $(13.9$ vs $33.1 \%, \mathrm{p}<0.05)$, and an increase in aqueous-phase lipid concentration $(10.4$ vs $6.6 \mathrm{mmol} / \mathrm{l}, \mathrm{p}<0.05)$. On taurine, the proportion of taurine conjugated bile acids increased (67 vs $22 \%, \mathrm{p}<0.01)$, but there was no significant change in bile acid precipitation or lipid solubilisation. Lower jejunal samples were aspirated similarly from five of these patients on no treatment, and all were at $\mathrm{pH}>6$; apparent 'precipitation' was reduced (16.4 vs $28.1 \%$ ), but lipid solubilisation did not improve. These findings suggest that $\mathrm{pH}$ dependent bile acid precipitation can limit lipid solubilisation within the jejunum after ileal resection, and that these effects can be reduced by cimetidine but not by taurine. Cimetidine may have a role in ileal resection patients with severe steatorrhoea unresponsive to dietary fat restriction.

Many patients suffer severe steatorrhoea after ileal resection; the severity is related to the length of ileum resected. ${ }^{12}$ Current treatment is non-specific and consists of a low fat diet, but such restriction is irksome and often unsuccessful. An approach to more specific treatment demands an understanding of the pathophysiology of the steatorrhoea.

Intraluminal bile acid deficiency provides one mechanism contributing to the steatorrhoea after ileal resection. Faecal loss of bile acid increases markedly after ileal resection,,$^{23}$ as the ileum is the site of active reabsorption of bile acid. ${ }^{45}$ In patients with a large ileal resection the liver is no longer able to compensate adequately by increasing bile acid synthesis, so that total jejunal bile acid concentration falls, ${ }^{1} 26$ especially during the third meal of the day. ${ }^{7}$ Intraluminal precipitation of bile acid provides

Address for correspondence: Dr T C Northfield, Department of Medicine II, St George's Hospital Medical School, Cranmer Terrace, London SW17 0RE. Received for publication 9 April 1985 a second mechanism. Precipitation of up to $50 \%$ of total bile acid has been reported in a study of eight ileal resection patients. ${ }^{8}$ Such precipitation may critically reduce aqueous-phase bile acid concentration in ileal resection patients who already have a low total bile acid concentration.

The mechanism of this bile acid precipitation in ileal resection has not been studied, although it is reported to affect predominantly the glycineconjugated bile acids. ${ }^{8}$ Our hypothesis is that this precipitation is mediated by acid, because (a) in vitro studies have shown that glycine conjugated bile acids precipitate below $\mathrm{pH} 5$, whereas taurine conjugates do not precipitate till $\mathrm{pH}$ falls below $2:{ }^{9}$ an increased proportion of glycine-conjugated bile acids is found after ileal resection, ${ }^{16}{ }^{10} 11$ thus increasing the susceptibility of these patients to such precipitation; (b) $\mathrm{pH}$-probe studies have shown that duodenal $\mathrm{pH}$ falls below 5 for $30 \%$ of a 100 minute postprandial period even in normal subjects: ${ }^{12}$ it 
might fall below 5 to an even greater extent in patients with an extensive ileal resection as gastric acid hypersecretion has been demonstrated in such patients. ${ }^{1314}$ This hypothesis would suggest that a histamine $\mathrm{H}_{2}$-receptor antagonist such as cimetidine might prevent bile acid precipitation by decreasing gastric acid secretion, while administration of taurine might reduce the proportion of bile acids susceptible to precipitation by increasing the proportion of taurine conjugates. ${ }^{15}$ Either treatment might thus improve lipid solubilisation.

We have therefore studied the relationship between $\mathrm{pH}$, bile acid precipitation and aqueous solubilisation of lipid, and the effect of cimetidine and taurine on these factors, in postprandial upper jejunal aspirate from nine ileal resection patients. In five patients we also examined whether any abnormalities found in the upper jejunum were reversed in the lower jejunum, as $\mathrm{pH}$ is known to rise further down the small bowel in health. ${ }^{16}$

\section{Methods}

\section{SUBJECTS}

Upper jejunal samples were obtained from nine ileal resection patients (subjects 1-9 in Table 1). None of the patients with Crohn's disease had residual activity or strictures. Patient number 4 had an ileostomy in addition to an extensive ileal resection. Six patients had steatorrhoea (faecal fat excretion more than $18 \mathrm{mmol} / 24 \mathrm{~h}$ as an inpatient on a five day stool collection after a two day run in period on a $100 \mathrm{~g}$ fat diet), but in only one was it severe (106 $\mathrm{mmol} / 24 \mathrm{~h}$ ). In the eight patients in whom it was appropriate the ${ }^{14} \mathrm{C}$-glycocholate acid breath test ${ }^{17}$ was abnormal; the test was inapplicable in the patient with the ileostomy. None of the patients had deconjugated bile acids in postprandial jejunal aspirate, suggesting that the abnormal breath tests resulted from increased bile acid deconjugation in the colon, and indicating interruption of the enterohepatic circulation of bile acid owing to ileal malabsorption. Samples were also aspirated from the lower jejunum in five subjects on no treatment (patients 2, 4, 5, 7, and 10 in Table 1); the distance of the lower aspiration site beyond the duodenojejunal flexure is shown in Table 1.

\section{EXPERIMENTAL DESIGN}

Each patient was treated with three different regimens given in random order for two weeks each, according to a Latin square design: (1) cimetidine $400 \mathrm{mg}$ four times daily 40 minutes before meals and at bedtime; (2) taurine $3 \mathrm{~g}$ three times daily at mealtimes; and (3) placebo matched with cimetidine. At the end of each treatment period, postprandial upper jejunal aspiration was performed. On that morning, treatment was given via the tube 35 minutes before the meal and as follows: for (1) a solution of cimetidine $400 \mathrm{mg}$; for (2) and (3) placebo solution. Lower jejunal aspiration was performed on the day after (3).

\section{UPPER JEJUNAL ASPIRATIONS}

A triple lumen tube with mercury bougie and balloon was used: one lumen for aspiration of samples, the second to act as an air inlet, and the third for subsequent inflation of the balloon to aid passage of the tube down the intestine. The tube was passed through the nose to the duodenojejunal flexure under fluoroscopic control; its position was confirmed radiologically at the end of the test. The patient was given a Lundh test meal $(40 \mathrm{~g}$ dextrose, $15 \mathrm{~g}$ skimmed milk powder dissolved in $230 \mathrm{ml}$ water and thoroughly mixed with $18 \mathrm{~g}$ corn oil). Aspiration was carried out as described previously ${ }^{18}$ and the method is given here in abbreviated form. As much jejunal content as possible was collected continu-

Table 1 Clinical details

\begin{tabular}{|c|c|c|c|c|c|}
\hline $\begin{array}{l}\text { Patient } \\
\text { (no) }\end{array}$ & $\begin{array}{l}\text { Age } \\
(y r)\end{array}$ & Sex & $\begin{array}{l}\text { Indication for } \\
\text { ileal resection }\end{array}$ & $\begin{array}{l}\text { Faecal fat } \\
\text { (mmol/24h) }\end{array}$ & $\begin{array}{l}\text { Lower jejunal sampling: distance of } \\
\text { aspiration site beyond } D J \text { flexure }(\mathrm{cm})\end{array}$ \\
\hline 1 & 52 & $\mathbf{F}$ & Volvulus due to adhesions & $18 \cdot 4$ & - \\
\hline 2 & 49 & $\mathbf{M}$ & Crohn's disease & $19 \cdot 9$ & $58 \cdot 5$ \\
\hline 3 & 59 & $\mathbf{M}$ & Crohn's disease & $24 \cdot 2$ & - \\
\hline $4^{*}$ & 41 & $\mathbf{M}$ & Crohn's disease & $105 \cdot 6$ & 25 \\
\hline 5 & 26 & $\mathbf{F}$ & Crohn's disease & $21 \cdot 5$ & 63 \\
\hline 6 & 43 & $\mathbf{F}$ & Crohn's disease & $11 \cdot 5$ & - \\
\hline 7 & 49 & $\mathbf{F}$ & Volvulus & $13 \cdot 0$ & 27 \\
\hline 8 & 35 & $\mathbf{M}$ & Crohn's disease & $28 \cdot 1$ & - \\
\hline 9 & 38 & $\mathbf{F}$ & Crohn's disease & $13 \cdot 8$ & - \\
\hline $10 \dagger$ & 69 & $\mathbf{F}$ & Volvulus due to adhesions & $82 \cdot 7$ & 39 \\
\hline
\end{tabular}

* Ileostomy patient

† No samples on cimetidine and taurine. 
ously by syphonage and syringe aspiration into ice-cooled $10 \mathrm{ml}$ measuring cylinders. The $\mathrm{pH}$ of each $3 \mathrm{ml}$ sample was measured immediately with a glass electrode. Half of each sample was treated immediately with acid to inactivate lipase, and the treated and untreated samples pooled separately according to initial $\mathrm{pH}(<5,5-6,>6)$ and time (1st, 2nd, 3rd hour) as described previously (Fig. 1). ${ }^{18}$

\section{LOWER JEJUNAL ASPIRATIONS}

In those volunteering for a two day study on placebo, the balloon was inflated with $20 \mathrm{cc}$ of air after finishing the first day's test and allowed to travel to a maximum distance of $90 \mathrm{~cm}$ beyond the duodenojejunal flexure over the next 20 hours on a normal diet. The following morning the abdomen was radiographed to ensure that the tube had not entered the large bowel. The distance the tube travelled was measured (see Table 1) and postprandial aspiration performed as on the previous day.

LABORATORY PROCEDURES (FIG. 1)

Samples were analysed as described previously, ${ }^{18}$ except that trypsin and lipase were not measured. In brief, each treated pool was analysed for total saponifiable lipid and fatty acid concentrations after restoration to its original $\mathrm{pH}$, and each untreated pool for bile acid concentration. The aqueous phases were separated by ultracentrifugation overnight at $100000 \mathrm{~g}$, removed in their entirety, mixed and analysed for lipid and fatty acid (treated pools) and bile acid (untreated pools). In addition, glycinetaurine ratios were measured enzymatically after separation by thin layer chromatography; ${ }^{19}$ the solvent system used was chloroform:ethanol:acetic acid:water (12:8:4:1).

MATHEMATICAL AND STATISTICAL ANALYSIS

Derivations were calculated, and the separate pools weighted for volume were pooled by $\mathrm{pH}$ or hour mathematically, as described before ${ }^{18}$ (measured $\mathrm{pH}$ values were converted to $\mathrm{H}^{+}$-ion concentrations before pooling). The Wilcoxon signed rank test (two-tailed) was used to compare results between the different treatment regimens. Results were expressed as mean \pm SEM.

\section{Results}

(a) UPPER JEJUNUM: PLACEBO RESUlTS

Comparison of $\mathrm{pH}$ pools (Table 2)

Jejunal aspirate of $\mathrm{pH}<5$ was obtained from only four subjects; for this reason, statistical comparison of the $\mathrm{pH}<5$ and $\mathrm{pH}>6$ pools was considered unjustifiable. The proportions of aspirate (based on lipid recovery) recovered at $\mathrm{pH}<5$ were $8 \%, 14 \%$, $57 \%$ and $69 \%$ for patient numbers $1,2,4$ and 7 respectively.

Total fatty acid concentrations and lipolysis were lower at $\mathrm{pH}<5$ than at $\mathrm{pH} 5-6$ and $\mathrm{pH}>6$. Half of the total available bile acid was precipitated at $\mathrm{pH}$ $<5$, considerably more than at $\mathrm{pH}>6$ (Fig. 2), so that there was a marked $\mathrm{pH}$-gradient for aqueousphase bile acid concentration; at $\mathrm{pH}<5$ the mean concentration of bile acid remaining in solution was only $1.8 \mathrm{mmol} / \mathrm{l}$. This led to a marked reduction in aqueous-phase lipid and fatty acid concentrations at $\mathrm{pH}<5$.

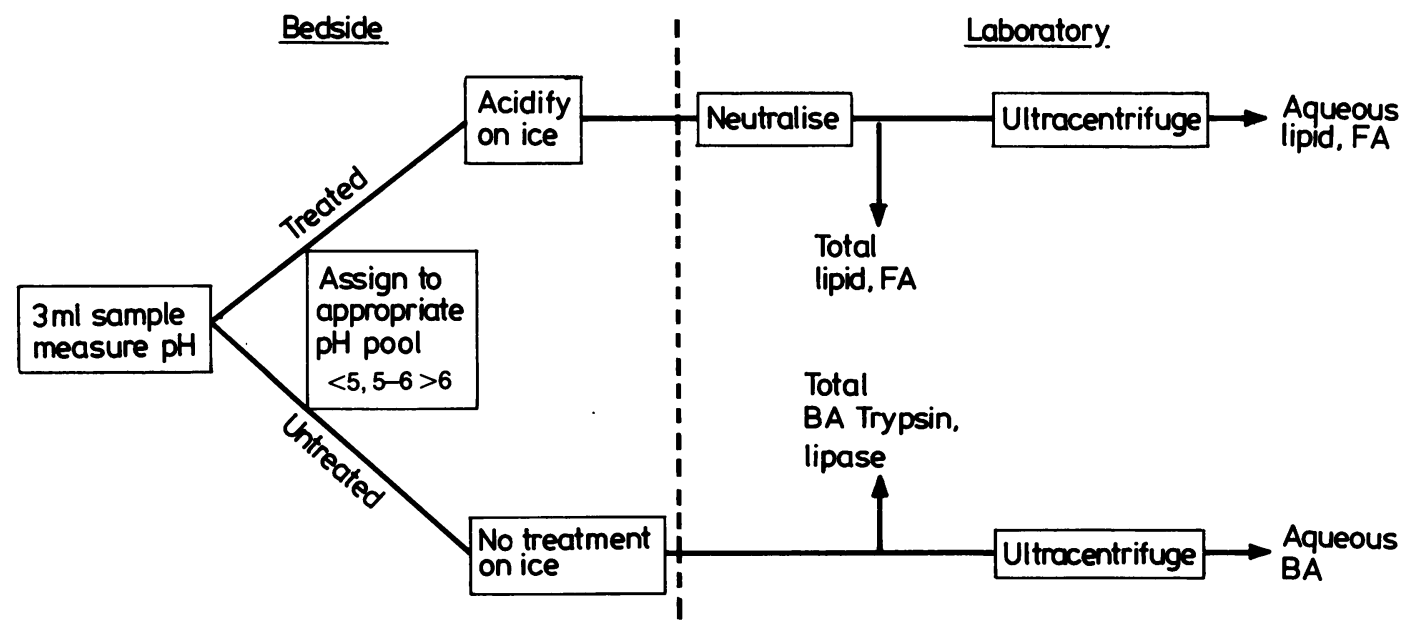

Fig. 1 Processing of samples of jejunal aspirate. 
Table 2 Comparison of pH pools on placebo

\begin{tabular}{|c|c|c|c|}
\hline & $p H<5$ & pH 5-6 & $p H>6$ \\
\hline $\begin{array}{l}\text { Lipid recovery (\% of total } \\
\text { recovered) }\end{array}$ & $13 \cdot 1 \pm 6 \cdot 3$ & $19 \cdot 1 \pm 9 \cdot 5$ & $67 \cdot 8 \pm 11 \cdot 6$ \\
\hline $\begin{array}{l}\text { Total bile acid }(\mathrm{mmol} / \mathrm{l}) \\
\text { Aq-phase bile acid }(\mathrm{mmol} / \mathrm{l}) \\
\text { Bile acid precipitation }(\%)\end{array}$ & $\begin{array}{r}4 \cdot 0 \pm 0 \cdot 9 \\
1 \cdot 8 \pm 0 \cdot 1 \\
50 \cdot 5 \pm 9 \cdot 3\end{array}$ & $\begin{array}{r}4 \cdot 4 \pm 0 \cdot 8 \\
2 \cdot 3 \pm 0 \cdot 5 \\
39 \cdot 2 \pm 6 \cdot 9\end{array}$ & $\begin{array}{r}6 \cdot 8 \pm 0 \cdot 7 \\
4 \cdot 7 \pm 0 \cdot 6 \\
26 \cdot 1 \pm 2 \cdot 9\end{array}$ \\
\hline $\begin{array}{l}\text { Total lipid }(\mathrm{mmol} / \mathrm{l}) \\
\text { Total fatty acid }(\mathrm{mmol} / \mathrm{l}) \\
\text { Lipolysis }(\%)\end{array}$ & $\begin{array}{r}59 \cdot 6 \pm 25 \cdot 6 \\
2 \cdot 9 \pm 0 \cdot 3 \\
14 \cdot 1 \pm 6 \cdot 7\end{array}$ & $\begin{array}{l}44 \cdot 8 \pm 12 \cdot 0 \\
16 \cdot 5 \pm 2 \cdot 5 \\
52 \cdot 8 \pm 18 \cdot 5\end{array}$ & $\begin{array}{l}43 \cdot 4 \pm 7 \cdot 2 \\
17 \cdot 4 \pm 4 \cdot 5 \\
47 \cdot 0 \pm 5 \cdot 7\end{array}$ \\
\hline $\begin{array}{l}\text { Aq-phase lipid }(\mathrm{mmol} / \mathrm{l}) \\
\text { Aq-phase fatty acid }(\mathrm{mmol} / \mathrm{l}) \\
\text { Proportion of fatty acid in aq } \\
\text { phase }(\%)\end{array}$ & $\begin{array}{l}5 \cdot 1 \pm 1 \cdot 0 \\
0 \cdot 6 \pm 0 \cdot 4\end{array}$ & $\begin{array}{l}5 \cdot 3 \pm 1 \cdot 4 \\
1 \cdot 7 \pm 0 \cdot 8\end{array}$ & $\begin{array}{l}8 \cdot 2 \pm 1.9 \\
5 \cdot 4 \pm 1 \cdot 9\end{array}$ \\
\hline
\end{tabular}

Comparison of hourly pools (Table 3)

A small reduction in $\mathrm{pH}$ from the first to the third hour was accompanied by a tendency to increased bile acid precipitation; this led to a significant reduction in aqueous-phase bile acid concentration and an associated reduction in the proportion of fatty acid solubilised, lipolysis remaining constant.

CIMETIDINE RESUlts (Tables 3 and 4)

$\mathrm{pH}$ Remained above 6 throughout the test in all patients except number 4 , in whom it fell slightly towards the end of the third hour. The reduction in $\mathrm{pH}$ in the third hour on placebo was corrected by cimetidine (Table 3 ). Overall $\mathrm{pH}$ was significantly higher on cimetidine than on placebo (Table 4).

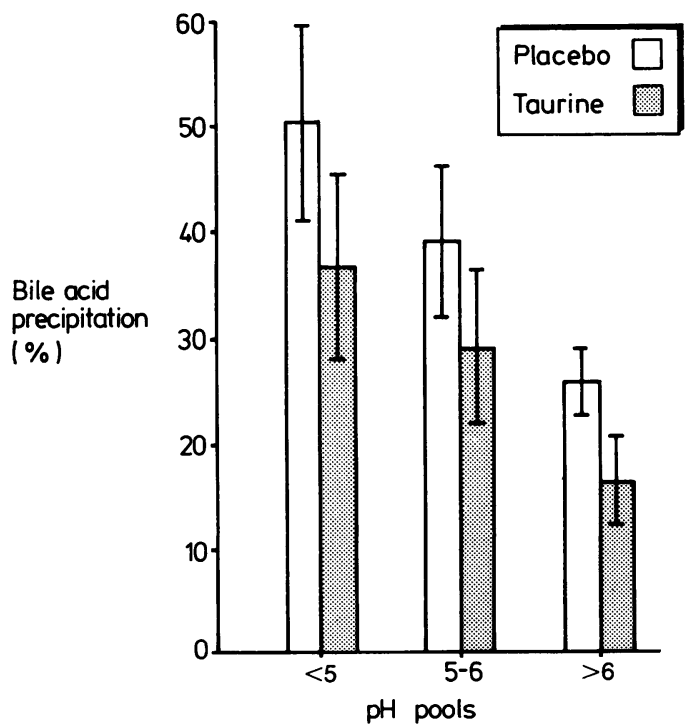

Fig. 2 pH Gradient for bile acid precipitation on placebo and taurine.
Table 3 Comparison of hourly pools on placebo and cimetidine (cimetidine values in italics)

\begin{tabular}{lccc}
\hline & 1st hour & 2nd hour & 3rd hour \\
\hline $\mathrm{pH}$ & $6 \cdot 3 \pm 0 \cdot 3$ & $6 \cdot 3 \pm 0 \cdot 2$ & $5 \cdot 8 \pm 0 \cdot 3$ \\
& $6 \cdot 7 \pm 0 \cdot 1$ & $6 \cdot 7 \pm 0 \cdot 1$ & $6 \cdot 6 \pm 0 \cdot 2^{*}$ \\
Total bile acid (mmol/l) & $6 \cdot 3 \pm 0 \cdot 9$ & $4 \cdot 8 \pm 0 \cdot 5$ & $4 \cdot 9 \pm 0 \cdot 7$ \\
& $9 \cdot 4 \pm 1 \cdot 9$ & $5 \cdot 3 \pm 0 \cdot 8$ & $5 \cdot 3 \pm 0 \cdot 7$ \\
Aq-phase bile acid (mmol/l) & $4 \cdot 8 \pm 0 \cdot 9$ & $3 \cdot 6 \pm 0 \cdot 5$ & $3 \cdot 3 \pm 0 \cdot 5 \dagger$ \\
& $7 \cdot 6 \pm 1 \cdot 9^{*}$ & $3 \cdot 7 \pm 0 \cdot 5$ & $4 \cdot 5 \pm 0 \cdot 9^{*}$ \\
Bile acid precipitation (\%) & $24 \cdot 4 \pm 5 \cdot 8$ & $27 \cdot 1 \pm 6 \cdot 5$ & $33 \cdot 1 \pm 5 \cdot 3$ \\
& $21 \cdot 6 \pm 5 \cdot 9$ & $25 \cdot 8 \pm 9 \cdot 9$ & $14 \cdot 0 \pm 4 \cdot 4^{*}$ \\
Lipolysis (\%) & $42 \cdot 2 \pm 7 \cdot 9$ & $55 \cdot 4 \pm 9 \cdot 7$ & $39 \cdot 1 \pm 7 \cdot 6$ \\
& $31 \cdot 3 \pm 10 \cdot 0$ & $36 \cdot 3 \pm 7 \cdot 2$ & $45 \cdot 2 \pm 8 \cdot 6$ \\
Aq-phase lipid (mmol/l) & $9 \cdot 5 \pm 2 \cdot 3$ & $8 \cdot 0 \pm 2 \cdot 7$ & $6 \cdot 6 \pm 2 \cdot 2$ \\
& $20 \cdot 6 \pm 5 \cdot 4^{*}$ & $12 \cdot 3 \pm 3 \cdot 9$ & $10 \cdot 4 \pm 2 \cdot 7^{*}$ \\
Proportion of fatty acid in & $44 \cdot 8 \pm 8 \cdot 4$ & $16 \cdot 2 \pm 5 \cdot 6$ & $29 \cdot 2 \pm 6 \cdot 7 \dagger$ \\
aq-phase (\%) & $49.3 \pm 15 \cdot 6$ & $16 \cdot 7 \pm 1 \cdot 7$ & $28 \cdot 5 \pm 7 \cdot 4$ \\
\hline
\end{tabular}

${ }^{*} \mathrm{p}<0.05$ cimetidine $v s$ placebo

$\dagger \mathrm{p}<0.051$ st hour $v s 3$ rd hour.

There was no significant change in total fatty acid concentration or lipolysis on cimetidine. The significant increase in $\mathrm{pH}$ in the third hour on cimetidine was associated with a significant reduction in bile acid precipitation and increase in aqueous-phase bile acid and lipid concentrations (Table 3 ). In the first hour aqueous-phase bile acid concentration also increased significantly, but this can be attributed to a higher total bile acid concentration. This was associated with a significant and marked increase in aqueous-phase lipid concentration. These improvements resulted in an overall increase in aqueousphase lipid concentration on cimetidine (Table 4).

TAURINE RESUlTS (Tables 4 and 5)

The proportions of jejunal aspirate recovered at each $\mathrm{pH}$, and the overall mean $\mathrm{pH}$ on taurine and on

Table 4 Overall three hour mean values

\begin{tabular}{lrrr}
\hline & Placebo & Cimetidine & Taurine \\
\hline pH & $5 \cdot 9 \pm 0 \cdot 3$ & $6 \cdot 5 \pm 0 \cdot 2 *$ & $5 \cdot 8 \pm 0 \cdot 3$ \\
Total bile acid (mmol/l) & $5 \cdot 3 \pm 0 \cdot 6$ & $6 \cdot 3 \pm 0 \cdot 8$ & $4 \cdot 5 \pm 0 \cdot 4$ \\
Aq-phase bile acid (mmol/l) & $3 \cdot 8 \pm 0 \cdot 5$ & $4 \cdot 8 \pm 0 \cdot 6$ & $3 \cdot 5 \pm 0 \cdot 5$ \\
Bile acid precipitation (\%) & $29 \cdot 2 \pm 1 \cdot 9$ & $22 \cdot 3 \pm 3 \cdot 9$ & $23 \cdot 7 \pm 4 \cdot 0$ \\
Total lipid (mmol/l) & $44 \cdot 6 \pm 7 \cdot 5$ & $61 \cdot 1 \pm 6 \cdot 3$ & $38 \cdot 3 \pm 4 \cdot 1$ \\
Total fatty acid (mmol/l) & $15 \cdot 6 \pm 4 \cdot 9$ & $21.9 \pm 8 \cdot 3$ & $12 \cdot 7 \pm 5 \cdot 2$ \\
Lipolysis (\%) & $42 \cdot 1 \pm 7 \cdot 5$ & $32 \cdot 9 \pm 8 \cdot 4$ & $28 \cdot 7 \pm 7 \cdot 0$ \\
Aq-phase lipid (mmol/l) & $8 \cdot 4 \pm 1 \cdot 8$ & $13 \cdot 5 \pm 3 \cdot 1 \dagger$ & $9 \cdot 4 \pm 2 \cdot 0$ \\
Aq-phase fatty acid (mmol/l) & $4 \cdot 8 \pm 2 \cdot 1$ & $7 \cdot 0 \pm 3 \cdot 2$ & $2 \cdot 6 \pm 0 \cdot 9$ \\
Proportion of fatty acid in & & & \\
aq-phase (\%) & $28 \cdot 8 \pm 6 \cdot 5$ & $29 \cdot 1 \pm 4 \cdot 6$ & $21 \cdot 9 \pm 3 \cdot 6$ \\
\hline
\end{tabular}

${ }^{*} \mathrm{p}<0.05$ Cimetidine $v s$ placebo

$+0 \cdot 10>p>0 \cdot 05$ (two-tailed test) Cimetidine $v s$ placebo. 
placebo were similar; statistical comparison of the $\mathrm{pH}<5$ and $\mathrm{pH}>6$ pools was again unjustifiable.

Total fatty acid concentration and lipolysis were also similar to those on placebo and showed similar $\mathrm{pH}$-gradients. The proportion of taurine conjugated bile acids rose from $22 \pm 3 \%$ on placebo and $18 \pm 4 \%$ on cimetidine, to $67 \pm 7 \%$ on taurine $(\mathrm{p}<0.01)$. Bile acid precipitation was slightly reduced at each $\mathrm{pH}$ but the pH-gradient remained (Fig. 2); overall bile acid precipitation was not significantly reduced. Similarly, the $\mathrm{pH}$-gradient for aqueous-phase bile acid concentration remained unaltered (Table 5) and overall aqueous-phase bile acid concentration did not improve (Table 4). Aqueous-phase lipid and fatty acid concentrations were therefore unaffected by taurine (Table 4 ).

\section{(b) LOWER JEJUNUM (Table 6)}

As samples were obtained from only five patients statistical comparison was unjustifiable. There was a clear change in $\mathrm{pH}$ profile from the upper to the lower jejunum. There was no $\mathrm{pH}<5$ aspirate and only one patient produced samples at $\mathrm{pH}<6$ in the lower jejunum (1.5\% of the meal). Values pooled over three hours were therefore used for comparison. This change in $\mathrm{pH}$-profile led to a reduction in bile acid precipitation to $16 \%$ (mean not significantly different from zero). Both total and aqueousphase bile acid concentrations were higher in the lower jejunum, leading to an increase in the proportion of lipid and fatty acid solubilised.

\section{Discussion}

Our first experiment showed marked intrajejunal bile acid precipitation at $\mathrm{pH}<5$ in untreated ileal resection patients, as predicted from in vitro studies. ${ }^{9}$ The appearance of apparent 'precipitation' at $\mathrm{pH}>6$, well above the relevant $\mathrm{pKa}$ values, suggests

Table 5 Comparison of $p H$ pools on taurine

\begin{tabular}{lrrr}
\hline & \multicolumn{1}{c}{$p H<5$} & \multicolumn{1}{c}{$p H 5-6$} & \multicolumn{1}{c}{$p H>6$} \\
\hline Lipid recovery (\% of total & & & \\
recovered) & $14 \cdot 5 \pm 8 \cdot 1$ & $19 \cdot 1 \pm 6 \cdot 2$ & $66 \cdot 4 \pm 12 \cdot 1$ \\
Total bile acid (mmol/l) & $1 \cdot 9 \pm 0 \cdot 3$ & $4 \cdot 1 \pm 0 \cdot 6$ & $6 \cdot 2 \pm 0 \cdot 9$ \\
Aq-phase bile acid (mmol/l) & $1 \cdot 3 \pm 0 \cdot 3$ & $3 \cdot 0 \pm 0 \cdot 6$ & $4 \cdot 4 \pm 0 \cdot 5$ \\
Bile acid precipitation (\%) & $36 \cdot 7 \pm 8 \cdot 7$ & $29 \cdot 3 \pm 7 \cdot 1$ & $16 \cdot 4 \pm 4 \cdot 3$ \\
Total lipid (mmol/) & $35 \cdot 0 \pm 13 \cdot 3$ & $34 \cdot 5 \pm 2 \cdot 8$ & $39 \cdot 1 \pm 4 \cdot 4$ \\
Total fatty acid (mmol/l) & $2 \cdot 2 \pm 0 \cdot 4$ & $8 \cdot 2 \pm 1 \cdot 3$ & $17 \cdot 2 \pm 5 \cdot 4$ \\
Lipolysis (\%) & $7 \cdot 3 \pm 1 \cdot 3$ & $23 \cdot 0 \pm 4 \cdot 8$ & $39 \cdot 9 \pm 6 \cdot 9$ \\
Aq-phase lipid (mmol/l) & $6 \cdot 6 \pm 2 \cdot 9$ & $6 \cdot 1 \pm 2 \cdot 7$ & $10 \cdot 7 \pm 1 \cdot 9$ \\
Aq-phase fatty acid (mmol/l) & $0 \cdot 2 \pm 0 \cdot 1$ & $1 \cdot 6 \pm 0 \cdot 2$ & $4 \cdot 1 \pm 0 \cdot 7$ \\
Proportion of fatty acid in & & & \\
aq-phase (\%) & $8 \cdot 0 \pm 3 \cdot 7$ & $20 \cdot 7 \pm 3 \cdot 3$ & $27 \cdot 5 \pm 4 \cdot 3$ \\
\hline
\end{tabular}

Table 6 Comparison of three hour mean values in upper and lower jejunum

\begin{tabular}{|c|c|c|}
\hline & Upper jejunum & Lower jejunum \\
\hline $\mathrm{pH}$ & $6 \cdot 0 \pm 0 \cdot 3$ & $6 \cdot 7 \pm 0 \cdot 3$ \\
\hline Total bile acid (mmol/l) & $5 \cdot 1 \pm 0.6$ & $8.9 \pm 2 \cdot 8$ \\
\hline Aq-phase bile acid (mmol/l) & $3 \cdot 7 \pm, 0 \cdot 5$ & $8 \cdot 4 \pm 3 \cdot 6$ \\
\hline Bile acid precipitation (\%) & $28 \cdot 1 \pm 2 \cdot 0$ & $16 \cdot 4 \pm 11 \cdot 3$ \\
\hline Total lipid (mmol/l) & $45 \cdot 3 \pm 6 \cdot 8$ & $16 \cdot 7 \pm 3 \cdot 8$ \\
\hline Total fatty acid (mmol/l) & $17 \cdot 1 \pm 4 \cdot 4$ & $12 \cdot 0 \pm 3.4$ \\
\hline Lipolysis (\%) & $43 \cdot 3 \pm 6 \cdot 5$ & $86 \cdot 2 \pm 26 \cdot 0$ \\
\hline Aq-phase lipid (mmol/l) & $8 \cdot 5 \pm 1.6$ & $6 \cdot 2 \pm 1 \cdot 9$ \\
\hline Aq-phase fatty acid (mmol/l) & $5 \cdot 1 \pm 1 \cdot 8$ & $5 \cdot 5 \pm 2 \cdot 0$ \\
\hline Proportion of fatty acid & $28.4+5.5$ & $42.5+10 . ?$ \\
\hline $\begin{array}{l}\text { In aq-pnase }(\%) \\
\text { Proportion of lipid in aq-phase }(\%)\end{array}$ & $\begin{array}{l}28 \cdot 4 \pm 5 \cdot 5 \\
19 \cdot 8 \pm 2 \cdot 4\end{array}$ & $\begin{array}{l}42 \cdot 3 \pm 10 \cdot 2 \\
37 \cdot 0 \pm 7 \cdot 6\end{array}$ \\
\hline
\end{tabular}

some additional mechanism other than that demonstrated in vitro using pure bile acid solutions. Both glycine and taurine conjugated bile acid bind to undigested protein in the meal, ${ }^{20}$ and this would appear as 'precipitation'.

The $\mathrm{pH}$-gradient for aqueous-phase lipid and fatty acid concentrations on no treatment can be attributed to a combination of the increased bile acid precipitation and decreased lipolysis demonstrated at $\mathrm{pH}<5$ (Table 2). The finding of a marked $\mathrm{pH}$-gradient for the proportion of total fatty acid in the aqueous-phase, however, suggests that bile acid precipitation must be the major factor as this expression eliminates the effect of lipolysis. Although none of these $\mathrm{pH}$-gradients could be tested statistically, the occurrence of similar gradients for all relevant measurements on placebo and on taurine support their validity. The finding of a reduction in fatty acid solubilisation in the aqueousphase from the first hour to the third hour, associated with a reduction in $\mathrm{pH}$, increased bile acid precipitation and reduced aqueous-phase bile acid concentration supports this interpretation, since lipolysis remained constant (Table 3 ).

The reduction in aqueous-phase bile acid concentration at low $\mathrm{pH}$ would assume greater importance if superimposed on a reduction in total bile acid concentration. ${ }^{12} 21121$ Our patients did not have a major reduction in overall bile acid concentrations $\left(5.3 \mathrm{mmol} / \mathrm{l}\right.$ vs $5.7 \mathrm{mmol} / \mathrm{ls}^{18}$ in our healthy subjects), or lipid solubilisation $(8.4 \mathrm{mmol} / \mathrm{l}$ vs 9.6 $\mathrm{mmol} / \mathrm{l}$ ) probably because only three of our patients had a resection of more than $100 \mathrm{~cm}$ and only one had severe steatorrhoea. Intraluminal bile acid deficiency $^{12}$ and gastric acid hypersecretion ${ }^{13} 14$ occur in patients with longer resections in whom these pH-dependent effects would therefore be more important. Furthermore, we studied only the first meal of the day and other studies have shown 
that a normal bile acid concentration at this time can be followed by a very low bile acid concentration during the second and third meal of the day. ${ }^{721}$

The cimetidine results confirm that in untreated patients $\mathrm{pH}$-dependent bile acid precipitation limits lipid solubilisation: overall bile acid precipitation and aqueous-phase bile acid concentrations (Table 4) were similar to the $\mathrm{pH}>6$ values on placebo (Table 2), suggesting that the improvement on treatment could be attributed to the abolition of pH-dependent bile acid precipitation (Table 2). In the first and third hours the increase in aqueousphase bile acid concentration was associated with an improvement in aqueous-phase lipid concentrations without any change in lipolysis (Table 3 ). This again shows the limiting effect of bile acid precipitation on lipid solubilisation. The overall improvement in $\mathrm{pH}$ on cimetidine was accompanied by a $60 \%$ improvement in aqueous-phase lipid concentration, and a $45 \%$ increase in aqueous-phase fatty acid concentration (Table 4), albeit insignificant.

Although treatment with taurine for two weeks successfully converted the majority of bile acids from glycine to taurine conjugates, it did not prevent bile acid precipitation (Table 4). Because taurine conjugates in pure solution do not precipitate above $\mathrm{pH} \mathrm{2,} \mathrm{the} \mathrm{persistence} \mathrm{of} \mathrm{apparent}$ $\mathrm{pH}$-dependent bile acid 'precipitation' was unexpected, but can be attributed to the protein binding already discussed. Thus treatment with taurine replaces the problem of $\mathrm{pH}$-dependent precipitation of glycine conjugates with that of $\mathrm{pH}$-dependent binding of taurine conjugates (Fig. 2). Furthermore, this bile acid binding appears to limit lipid solubilisation in the same way as bile acid precipitation, since similar $\mathrm{pH}$-gradients were observed for all measures of lipid solubilisation (Table 5).

Although mean bile acid precipitation in the lower jejunum did not differ significantly from zero, its presence at $\mathrm{pH}>6$ in some patients could be attributed to protein binding ${ }^{21}$ or to failure of complete reversal of precipitation. Comparison of the aqueous-phase fatty acid and lipid concentrations is complicated by the greater time available for lipolysis and absorption.

There has been a previous single case report describing improved lipid digestion and absorption due to cimetidine in a patient with an extensive ileal resection and gastric hypersecretion, ${ }^{22}$ and we have reported a significant reduction in faecal fat excretion in 14 patients with steatorrhoea due to ileal resection during treatment with cimetidine. ${ }^{23}$ This was not accompanied by a significant reduction in faecal wet weight, but another group has reported a significant reduction in faecal volume in 10 patients with diarrhoea due to ileal resection treated with cimetidine.${ }^{24}$ In our study, ${ }^{23}$ the reduction in faecal fat excretion was most marked in those with severe steatorrhoea, and cimetidine is therefore recommended in patients with severe steatorrhoea unresponsive to a low fat diet. Our finding of bile acid binding to undigested protein in both upper and lower jejunum may provide another mechanism contributing to the better effect of elemental rather than whole protein feeds in the short gut syndrome. $^{25}$

We would like to thank Smith, Kline, and French Laboratories for financial support, and Mrs Moya Gannon for nursing assistance.

\section{References}

1 Hofmann AF, Poley JR. Role of bile acid malabsorption in pathogenesis of diarrhoea and steatorrhoea in patients with ileal resection. Gastroenterology 1972; 62: 918-34.

2 Hofmann AF. Bile acid malabsorption caused by ileal resection. Arch Intern Med 1972; 130: 597-605.

3 Hardison WGM, Rosenberg IH. Bile salt deficiency in the steatorrhoea following resection of the ileum and proximal colon. $N$ Engl J Med 1967; 277: 337-42.

4 Borgstrom B, Lundh G, Hofmann AF. Site of absorption of conjugated bile salts in man. Gastroenterology 1963; 45: 229-38.

$5 \mathrm{Krag} \mathrm{E}$, Phillips SF. Active and passive bile acid absorption in man. $J$ Clin Invest 1974; 53: 1686-94.

6 McLeod GM, Wiggins HS. Bile-salts in small intestinal contents after ileal resection and in other malabsorption syndromes. Lancet 1968; 1: 873-6.

7 Van Deest BW, Fordtran JS, Morawski SG, Wilson JD. Bile salt and micellar fat concentration in proximal small bowel contents of ileectomy patients. J Clin Invest 1968; 47: 1314-24.

8 Poley JR, Hofmann AF. Role of fat maldigestion in pathogenesis of steatorrhoea in ileal resection. Gastroenterology 1976; 71: 38-44.

9 Small DM. The physical chemistry of cholanic acids. In: Nair PP, Kritchevsky D. eds. The bile acids. New York: Plenum Press, 1971: 1: 289.

10 Garbutt JT, Heaton KW, Lack L, Tyor MP. Increased ratio of glycine-to-taurine-conjugated bile salts in patients with ileal disorders. Gastroenterology 1969; 56: 711-20.

11 Mansbach CM, Newton D, Stevens RD. Fat digestion in patients with bile acid malabsorption but minimal steatorrhoea. Dig Dis Sci 1980; 25: 353-62.

12 Rune SJ, Viskum K. Duodenal $p$ values in normal controls and in patients with duodenal ulcer. Gut 1969; 10: 569-71.

13 Frederick PL, Sizer JS, Osbourne MP. Relation of massive bowel resection to gastric secretion. $N$ Engl J Med 1965; 272: 509-14.

14 Osbourne MP, Sizer JS, Frederick PL, Zamcheck N. Massive bowel resection and gastric hypersecretion. 
Am J Surg 1967; 14: 393-7.

15 Sjovall J. Dietary glycine and taurine on bile acid conjugation in man. Proc Soc Exptl Biol Med 1959; 100: $676-8$.

16 Borgstrom B, Dahlquist A, Lundh G, Sjovall J. Studies of intestinal digestion and absorption in the human. $J$ Clin Invest 1957; 36: 1521-36.

17 James OFW, Agnew JE, Bouchier IAD. Assessment of the ${ }^{14} \mathrm{C}$-glycocholic acid breath test. $\mathrm{Br}$ Med J 1973; 3: 191-5.

18 Zentler-Munro PL, Fine DR, Fitzpatrick WJF, Bird R, Northfield TC. Effect of intrajejunal acidity on lipid digestion and aqueous solubilisation of bile acids and lipids in health, using a new simple method of lipase inactivation. Gut 1984; 25: 491-9.

19 Hofmann AF. Thin-layer absorption chromatography of free and conjugated bile acids on silicic acid. J Lipid Res 1962; 3: 127-8.

20 Lanzini A, Bird R, Fitzpatrick WJF, Zentler-Munro
PL, Northfield TC. Bile acid binding to dietary protein. [Abstract] Gut 1981; 22: A441.

21 Westergaard $H$. Duodenal bile acid concentrations in fat malabsorption syndromes. Scand J Gastroenterol 1977; 12: 115-22.

22 Cortot A, Fleming CR, Malagelada J-R. Improved nutrient absorption after cimetidine in short-bowel syndrome with gastric hypersecretion. $N$ Engl J Med 1979; 300: 79-80.

23 Northfield TC, Zentler-Munro PL, Fitzpatrick WJF, Fine DR. Treatment of pancreatic and ileectomy steatorrhoea. In: Cimetidine in the 80's. Edinburgh: Churchill Livingstone, 1981: 208-14.

24 Aly A, Barany F, Kollberg B, Monsen A, Wisen O, Johansson $\mathrm{C}$. Effect of an $\mathrm{H}_{2}$-receptor blocking agent on diarrhoeas after extensive small bowel resection in Crohn's disease. Acta Med Scand 1980; 207: 119-22.

25 Silk DBA. Physiology of protein absorption. Res Clin Forums 1979; 1: 29-34. 